\title{
An Evaluation of the Global Orientation of English Textbooks in Germany
}

Mona Syrbe

Centre for Language and Communication Studies

Trinity College Dublin, The University of Dublin

Dublin D02, Ireland

syrbem@tcd.ie

Heath Rose

The Department of Education

The University of Oxford

Oxford OX2 6PY, United Kingdom

heath.rose@education.ox.ac.uk

This article investigates textbooks used in English classes in German schools to evaluate their relevance to current trends of teaching English as an international language. For many European students, English is no longer just a foreign language, but an important European lingua franca. Thus, we argue it is essential for the language to be positioned as such in key textbooks used in English classrooms, which aim to prepare students for future use of English. An analysis of three main textbook series used in Germany was done through an adapted framework that depicts a Global Englishes approach to language teaching, focussing on representations of ownership, users, models and target interlocutors of English. The analysis found that there was over-reliance of UK models of English, and static depictions of language users and cultures. The findings can be generalized to other countries where the sociolinguistic reality of English may not be accurately represented in English teaching materials.

Key words: Globalisation, Teaching Materials, Textbooks, Second Language Learning, English Language Teaching, English as a Lingua Franca

\section{Introduction}

This article aims to assess the global orientation of the ELT materials used in German high schools as part of the country's English language curriculum. Germany is an important country in the European Union, and plays a vital role in the region's politics, economy, and wider society. Language education, therefore, is vital to the development of students' knowledge of European languages, of which English as a lingua franca is playing an increasingly dominant role. English is quickly becoming the preferred lingua franca for Europeans, and consequently German students are more likely to use English in contact situations with other speakers from the expanding circle as opposed to speakers from within the inner circle, who have traditionally been posited as the target interlocutor in German ELT materials. Inner and expanding circle refers to Kachru's Concentric Circles model (Kachru 1985), in which he identifies three different English speech communities. The inner circle is comprised of those countries where English serves as a first language (although many speakers in the inner circle speak English as an additional language); the outer circle are those former colonies where English serves as a second language (although many speakers of English in the outer circle are native speakers); the expanding circle includes countries where 
English had no historical intra-national function but is taught in school (although English is growing in presence as a lingua franca language). Despite limitations of this categorization, it remains an influential model of the spread of English. Thus while we use the terminology of Kachru's model in this article, we also acknowledge the substantial criticisms surrounding it (see, Bruthiaux 2003). With the growth of ELF in Europe, this paper aims to assess whether ELT materials in Germany are preparing students for lingua franca usage of English, or whether they are promoting traditional, and unrepresentative, depictions of future English use. The paper begins with an exploration of the importance of the 'Global' in ELT practices, before exploring the needs of European students engaged in English language studies. The study into ELT materials is then described, before the results are presented and discussed. The article concludes with implications from this small study of the German educational context to Europe as a whole.

With the growth of English as a global language, the needs of students learning the language have rapidly changed. The past 50 years has seen English grow from the language of the United Kingdom, its historical colonies and territories, and its diaspora to a global lingua franca. The sociolinguistic landscape of English in use today is that on a worldwide scale, with a global community of users. The reality of this change in language use means that users in the expanding circle, who were historically defined as 'foreign language learners', have needs that extend beyond 'foreign' language use. Many of these users now have a need to use the language within their own national borders, within their own workplaces, and with other expanding circle users of the language. The changing sociolinguistic landscape of English has been the subject of study in a number of interrelated research fields: English as a Lingua Franca, World Englishes, and English as an International Language_-all of which have a shared endeavor to innovate the way the English language is viewed, and, by implication, the way the language is learned and taught.

World Englishes research is concerned with the identification and description of geographically and nationally bound varieties and their codification, which has highlighted the plurality of English. Accordingly, World Englishes scholars have argued for a more accurate portrayal of this variation in language teaching classrooms, rather than adherence to spoken 'standards' such as Received Pronunciation or General American, or prescriptive written 'standards', which do not accurately represent the majority of the English language in use. D'Souza (1999), in a special symposium issue of World Englishes on "Standards, Codification and World Englishes" argued that it would be more pedagogically sound to expose learners to as many varieties of English as possible than to continue current practices of imposing a single standard on everyone. ELF research has extended the work of World Englishes research in its examination of how the language is used within and across these linguistic communities. Rather than with geographical varieties, ELF is concerned with the use of English as a contact language between speakers of different first languages. ELF, in that sense, is not a variety of English but describes a kind of communication, in which the language is understood as virtual and transient in nature, highly variable according to interlocutors and the communicative goal of the interaction. Mauranan, for example, states that "Imposed standards are different from the natural norms that arise in groups and communities primarily in face-to face interaction to regulate interaction in the interests of mutual intelligibility and smooth communicative progress" $(2012,6)$. Such research also highlights the need for students become familiar with the language norms of various communities of practice, and be adaptable to move from one speech community to another. English as an international language has also pushed a political agenda to increase exposure to variation in English in the language classroom. McKay (2012), for example, has argued 
that language teachers are responsible to prepare learners to use English in global contexts, and thus they need to develop an awareness that speakers use English very differently from prescribed standards depicted in most language teaching classrooms. Matsuda and Friedrich (2012) examined language teaching materials in particular and discuss three options to take a more global perspective of language variation: choosing the most salient variety to students; using the speakers own variety; or using an established variety in tandem with exposure to other varieties. However, teachers who want to pursue this type of innovation in their teaching face a formidable barrier of a lack of materials that depict non-prescribed varieties.

A second implication of World Englishes, ELF, and EIL research on English language is the need to showcase a shift in ownership of the language as depicted in language teaching classrooms and materials, as well as the target cultures and speakers associated with English's global usage. World Englishes scholars, such as Mufwene (2001), have expressed disagreement with the treatment of Englishes of the Outer Circle as 'illegitimate' offspring of English, arguing that they have evolved from English due to language contact in much the same way as most inner circle varieties. In the face of recent research in applied linguistics, Leung and Street have argued that "the unquestioned assumption that the language norms and practices associated with native-speaker varieties should be regarded as automatically relevant and legitimate has been considerably lessened" (2012,88). In general ELF research has argued that educators need to encourage their students to move away from monocultural and monolingual norms that underpin much classroom practice to "look at the communicative practices of multilingual and multicultural speakers to understand ELF communication" (Baker 2012, 46). EIL researchers such as Friedrich offer a similar line of argument: "If the only constant in lingua franca situations is diversity, then we should anchor our practices in that assumption and educate students to encounter such diversity with respect, curiosity and wisdom" $(2012,50)$. Thus the three fields of World Englishes, ELF, and EIL share a fundamental ideology that English belongs to a global community of users, thus learners need to embrace their positions as multilingual users of the language, and need to be made fully aware that for many of them, they will be using the language to interact with a wide spectrum of language users, some of which may be inner circle speakers in inner circle cultures, but many of which will not.

\section{Background to the Study: English as a European Lingua Franca}

In Europe, English is used as a contact language between individuals from different countries to communicate with each other. Naturally, these include native English speakers from the UK and Ireland, but the majority of English use is between speakers whose native language is not English but one of many other native European languages. As Europe's lingua franca, English serves as a communicative tool in an array of domains: it is prevalent in education, the work place and the public sphere of Europeans. Globalization, the increase in mobility and the integration of Europe has only intensified this phenomenon (Hoffmann 2000). Though multilingualism is emphasized in the European Union, English is by far the most taught foreign language in Europe, with $90 \%$ of school children learning the language (European Commission 2012). English has become the de facto working language in the EU, and this influence also extends to day-to-day communication. In higher education, English attracts an international student body to complete full degrees abroad, or to engage in exchange programmes, which are increasingly offering courses taught through English in order to accommodate a linguistically diverse student body (Berns et al. 2007). Brenn-White $\&$ Faethe (2013) report an indicated increase of 1,000\% of English-medium masters programmes catering for international mobility in mainland Europe in the past ten years. 
They also report that Germany was only second to The Netherlands in the number of Englishtaught masters offered in 2013. In the workplace, English takes a salient position, most prominently in the areas of business and international relations (Breiteneder 2009).

In addition to the use of English as the language for education, it is used for international communication at meetings and conferences, and some European companies even use it for internal communication (Berns et al. 2007). In science, the vast majority of texts are published in English and most academic journals, international or not, have completely switched to English (Montgomery 2013). Scientists further report English as their de facto working language (Berns et al. 2007; Seidlhofer, 2006). Accordingly, proficiency in English is required for a variety of jobs, 'it has become the language of bus drivers and scientists alike' (Breiteneder 2009, 256). A bus driver might have to answer tourists' questions, a retail assistant may have to advise foreign customers, a doctor could have a foreign student as their patient, all of these most likely in English. German students might also want to seek work outside of Germany on the European job market, which is very common nowadays, further increasing their exposure to and need to communicate in English with other non-native speakers. It is often argued that English has most strongly impacted the public domain, most of all the media, as Europeans are most commonly come into contact with English through TV, radio, print, and music (Berns et al. 2007; Seidlhofer, Breiteneder, and Pitzl 2006). English is by far the most common foreign language in Germany, and is spoken by $56 \%$ of Germans to a proficiency level that allows them to hold a conversation (European Commission 2012). More important in this context, however, are the immediate uses of English as a language for travel and the internet, where Germans most often use their foreign language skills. The internet constitutes a new medium for informal international communication as well as a major resource for information. Thus, it is unsurprising that $40 \%$ of Germans indicated that they are most likely to use English on the internet (European Commission 2012).

Hilgendorf (2007), in a qualitative study investigating the use of English by Germans, found that English plays a significant role in several domains in Germany. She identified the areas of politics and law, business and advertisement, as well as education and the academics as domains where English plays a significant role, though to varying degrees. Next to a number of lexical borrowings, which she found significant, it is especially the need for communication "within the supranational structures of Europe" (Hilgendorf 2007, 37), which has increased. Additionally, English is increasingly used for intranational communication in a number of companies, as not all of the workers are German speaking. She further found that English has gained major significance in the area of academia, especially in science and research. Furthermore, it is the most studied foreign language in Germany, with $78 \%$ of German school children learn English. Moreover, it is progressively used as a medium of instruction, in so-called bilingual education [Bilingualer Unterricht], in which certain subjects such as natural sciences, history, or geography are taught in English. In addition to that, English plays a central role in the media and pop culture, exerting major influence on youths and young adults. They are frequently exposed to English, be it on TV, in movies or via music, as even a large number German artists choose to sing fully or partially in English.

Therefore, English plays a major role in Germany, namely as a language for international communication in a variety of occupational areas. German students will use English in various diverse contexts in their private and work life. To Germans, English serves as a lingua franca, enabling them to communicate with Europeans who do not share their native language. As educators, we were therefore interested in investigating one simple research 
question: Do high-school textbooks properly meet the needs of German students to use English in such diverse contexts? The answer to this question is also of relevance to other European nations, for whom English plays an equally important role.

\section{Methodology}

\section{Research questions}

This investigation evaluated the global orientation of three popular English textbooks, which are widely used within the German English language curriculum. The aim of the study was to explore the extent to which these textbooks positioned English as an International Language, and whether these texts recognized the lingua franca status of English, which is termed Weltverkehrssprache in the state's curriculum [Kernlehrplan]. (Ministerium für Schule und Weiterbildung des Landes Nordrhein-Westfalen 2007). In the curriculum, it is stated that, in light of international cooperation and global competition, new extended requirements have emerged for English as a lingua franca, and ELT should aim at developing communicative and intercultural competence, as well as developing students' repertoire of linguistic resources [Verfügbarkeit sprachlicher Mittel] and multilingual profiles [Mehrsprachigkeitsprofil]. Thus, this study aimed to investigate the extent to which English's lingua franca position was reflected in textbooks. Although textbooks only provide one perspective into classroom practices, they remain most prevalent sources of teaching and as such assert a major influence on the way language is taught and the way students view the language (Matsuda 2002).

Specifically, the study aimed to answer the following research questions:

1. Who are positioned as the owners of English?

2. Who are the target interlocutors in the materials?

3. What models and norms of English are used in the book and audio materials?

4. How is culture depicted in the materials?

5. How are concepts related to the global use of English (e.g. English as a lingua franca) presented?

\section{Sampling}

The textbooks chosen for this evaluation were the three approved textbooks for the state of North-Rhine Westphalia: Camden Town, volume 6; Green Line, volume 6 and English G21, volume 5. These books were chosen as typical examples of texts used in the more advanced levels of English language studies, because it was thought that at the advanced levels, English as an international language would be able to take a central role, after the mechanics of the English language had been taught. The region of North-Rhine Westphalia was chosen because it is the most populous state in Germany, and is home to four of the ten biggest cities in Germany. Each state in Germany is free to set their own curriculum and their own textbook materials, although in practice many of the smaller states follow the innovations of the larger, resource-rich states. The study sought to choose a state that would be most representative of English language teaching approaches in Germany. Due to the political and populous clout of North-Rhine Westphalia, it was deemed as the most appropriate choice.

\section{Data analysis}


In order to evaluate the global orientation of the textbooks, a framework was developed from the literature according to each of the research questions. The framework was informed in part by Jenkins's (2006) EFL vs ELF framework (Table 1).

[Table 1 near here]

Because Jenkin's (2006) framework examines English use rather than teaching, ideas were also incorporated from Galloway and Rose's Global Englishes Language Teaching framework (Table 2), which summarized the proposals for innovation in English Language Teaching from World Englishes, EIL and ELF research.

[Table 2 near here]

The framework applied to this research examined how elements in the curriculum, such as target interlocutors, models of English, target cultures, and ownership of English, were illustrative of a traditional EFL approach, or a global Englishes approach. Thus, the textbooks were evaluated as falling on a spectrum with EFL-oriented ideology at one end, and ELF /Global Englishes ideology at the other. Only those items from the Jenkins (2006) and Galloway and Rose (2015) frameworks were included that could be directly observed in teaching materials (Table 3 ).

\section{[Table 3 near here]}

The evaluation also investigated whether there was direct teaching of concepts and ideas related to English as a lingua franca and English as an international language, for instance maps portraying the spread of English, the nativization of English in the outer circle or the requirements of ELF communication - notions seen as essential in shifting perceptions of how students will use English in the future.

\section{Results}

\section{Who are positioned as the owners of English?}

In order to establish who were depicted as the users of the language in the subtext of textbooks, all spoken and written depictions of communications between two or more people were analyzed in the authentic materials used in the books. Because the textbooks did not include 'main characters' as a common thread, the users of the language were identified in the authentic text excerpts, as these were seen as showcasing to learners who uses the English language in the 'real world'. In all three textbooks, the majority of characters' nationality were US-American or British but there were also a number of characters from Australia and South Africa. The first and partially the second unit of English G21 featured a number of Australian characters such as an Australian-German girl, and three Australian teenagers. Further, the characters in the book In the outback were Australian and so were the characters from the Luuurve Debate (English G21), and Looking for Alibrandi (Green Line). The book She doesn't speak by Marita Van de Vyer, depicted South African characters and so did The typewriter by Beverly Naidoo (Camden Town). Naidoo's other novel The other side of the truth showcased Nigerian main characters. Green Line illustrated Caribbean English in two poems, further elaborating on it in a Fact File. The remaining nine novels and short stories 
feature US-American and British characters, including two works by Kureishi which portrayed native English-speaking characters from Asian-English backgrounds.

Throughout the three textbooks books, there were 29 authentic materials excerpts that depicted real-world language use between speakers of English. Almost all of these (25) involved only native speakers of English, who were communicating within their own broad linguistic communities (e.g. within the inner circle, or within the outer circle). Thus, native speaker to native speaker discourse featured heavily, notably between US-Americans (11), British speakers (8), Australians (3), South Africans (2), Nigerians (1). There were only two instances of authentic materials discourse that depicted English use across national borders, between an English tourist and an Australian (1) and a Hong Kongese and Australian (1) the latter was the only native speaker to native speaker exchange that occurred across Kachru's Outer and Inner Circles. There was only one depiction of a language contact situation in the authentic texts, where a German student wrote a letter to his British host family. This is the only language exchange that could be identified as ELF usage, if defined as communication between speakers of different first languages. There were no instances of English use between non-native speakers in any of the real world materials presented in the books. These textbooks, therefore clearly posit English as the language of the inner circle, with some reference to Outer Circle speakers (Nigeria and Hong Kong), but certainly the language owned by native speakers. In the one example of non-native speaker use of English it was directed towards the native speaker as target interlocutor-the user of the language. Thus, such findings not do truly reflect the use of English as a global language; and do not reflect English as a language used across Kachru's three circles, with global ownership.

\section{Who are the target interlocutors in the materials?}

In order to establish the target interlocutors that were presented in the textbooks, tasks were identified in the textbooks, in which students were asked to imagine they were using English in real world scenarios. The target interlocutors in these situations were analyzed, as they positioned to students the likely receivers of perceived future use of English. In total 16 tasks were identified across all three textbooks which positioned students in a future scenario of using English. The majority of these $(n=13)$ depicted German students as either going to an Inner Circle country to communicate with native English speakers, or encountering native English speakers in Germany. In these scenarios, students were depicted as using English for purposes such as talking to their host family, obtaining information when sightseeing, or conversing with travellers or exchange students in Germany. Other scenarios included applying for a job or an exchange in an English-speaking country, in the form of a cover Letter, a resume, and a job interview. Other situations depicted the students encountering native speakers of English in Germany, who were there as exchange students; in these situations the learners had to communicate with these native speakers in English through both oral (e.g. spoken conversations) and written communication (e.g. email). A good proportion of situations required the learners to mediate a communication, by acting as a translator between native English speakers and native German speakers. Mediation was also the main assignment in many assessment tasks, where students had translate the gist of an English text into German, or the gist of a German text into English. The purpose of these tasks were rationalized to give information to either a German national who did not speak English, or native English speaker who did not speak German. Thus, the conveyed future use of English in these textbooks was to converse with native English speakers. Three tasks, however, conveyed the target interlocutor as an international audience: two tasks involved the writing 
of articles in English for European or international magazines, and one task required students to use English to apply for a job in mainland Europe.

\section{What models and norms of English are presented in the book and audio materials?}

In order to evaluate the models of English presented in the textbook, audio materials were evaluated to establish the dialect of English represented. Received pronunciation (RP) was clearly the dominant variety, and one text (English G21) introduced every audio track by the same speaker of RP English. In several tracks, audio portrayed American English, Australian English, and South African English accents. The only Outer Circle varieties were Jamaican English in a song by Bob Marley, and one speaker from Namibia in Camden Town. This textbook also included one communication between two European non-native speakers, one from Spain and one from Finland, which was the only depiction of lingua franca English usage between two non-native speakers. Pronunciation given in IPA symbols was entirely representative of RP English.

In order to draw conclusions about the written language models presented in the books, we inspected the main texts and tasks in each textbook for language usage that could be evaluated as differing from prescribed language models. All three books clearly favored a static variety of British English, which was always presented unmarked throughout the three textbooks, thus indicating its use as standard; when American English or other Englishes were presented, they were always accompanied with a marker, explanation, or footnote to indicate deviation from the books' standard usage of English. American English was often depicted as an acceptable and legitimate variety, with American English words presented alongside other vocabulary in English G21, marked $(A E)$. In Camden Town, we additionally found explicit information about some of the major differences in spelling between American and British English, which urged students to adhere to either variety throughout their writing. There was further variation in vocabulary usage, which usually coincided with a chapter on its country of use; for example, a unit on Australia in English 21 included some Australia lexis (e.g. Aussie, Barbie, Fair Dinkum), which was marked as to the reader as being different from the norm. Carribean English was also outlined in a related chapter on this region. In the vocabulary section of Green Line, students learned about South African English and were provided with a few words, used to illustrate differences from the British English meaning.

Unlike vocabulary, grammar norms throughout the textbooks followed clear, standard prescribed norms; none of the textbooks noted that grammar usage may diverge from prescribed standards. Moreover, the model of English used across the textbooks was largely depicted as stable and static; that is, there was little discussion of language changing over time or distances. One exception was noted in English G21, where Caribbean English was portrayed in two poems, which were accompanied by a short informational text informing students about the development and influences of English in that region.

\section{How is culture depicted in the materials?}

In English G21, students gain knowledge about the United States, the UK, and Australia. This book gave a large volume of explicit cultural information throughout the units. In the first unit, the Australian continent was portrayed and students received information about teenage life, and school through the eyes of a teenage girl moving to Melbourne. Further, 
Australian sports and life in the outback were portrayed through the eyes of Australian teenagers. Lastly, they learned about the Aboriginal people, their beliefs and their treatment during European settlement. The Text File at the end of the book further added to that knowledge by expanding on geography and wildlife of Australia, and introducing Australian arts and culture. As Australia was the only country that filled a whole unit, although information about the US and the UK were scattered throughout the book. Fact Files and tasks in the textbook taught students about the US system of government, the US constitution, volunteering in the US and community service. They learned about Britain being a multicultural society, the school system in Great Britain, the monarchy, and its political system today. Two further texts deal with criminality, especially among youths in England and Wales. Dev Patel was portrayed through a text and a corresponding reading comprehension quiz, where his work on Slum dog Millionaire was described. This text about the British-Indian actor briefly addresses life in the Indian slums and the Mumbai accent in English.

Camden Town was less explicit in its depictions of target cultures, relying to a higher degree on real world material. This book featured South Africa in one unit. Students were given milestones from Nelson Mandela's life and read further about South African music Kwaito, as well as the South African reverend Desmond Tutu. Students learned about the significance of the world cup for South Africa as a country, the history of apartheid, and the state of democracy in South Africa today. The other 5 units discussed social issues of teenage life, such as bullying and shopping, or global issues such as "world matters" or the media, which were not tied explicitly to national cultures. In unit 6, they learned about the British Sir Peter Ustinov and his involvement with UNICEF. As the majority of tasks refer to the real world material, there was no significant cultural information given in the remaining tasks.

Green Line, like Camden Town, worked with a large amount of real world material as well as high number of small items of culture-specific or person-specific information in so-called Fact Files and VIP Files. Unlike the other two books, Green Line did not cover a country or continent but did dedicated one unit to multicultural Britain. The other units cover global aspects similar to those in Camden Town and English G 21, with environment being a predominant topic.

All three series somewhat refer to English being an International Language mostly in terms of either immigrants to England, whose native cultures are portrayed, as is the case with multicultural London or a teacher who is from Jamaica. English G21 further introduces other cultural, when referring to 'Special days' in the US, the UK, India and New Zealand in the second book and introducing Canada in the third book. Green Line Series gives explicit advice on Intercultural Behavior, all with reference to the UK and the US, telling students how to avoid 'social gaffes'. The books point to multiculturalism within inner and outer circle countries, like multicultural London, multi-ethnic South Africa, or native communities in America and Australia. The depictions of culture across all books are static - that is, even if they are multicultural depictions, the message to students is clearly to prepare them for entering this static culture. There were no depictions in any of the books that show a fluid, diverse, and flexible cultures in lingua franca contexts.

\section{Do the textbooks teach concepts related to English as a lingua franca?}


At the end of English G21, there was a map of 'English speaking countries', providing the most explicit reference to English as an International Language in all three books. The map distinguished between English as a first language and English as an official language. The book also provides readers with a table listing the 'English speaking countries', including an estimated numbers of speakers of English as a first language and speakers of English as an additional language in these countries. Similarly, we found a map of 'The English speaking world', at the back of Camden Town. This map divided the English speaking world into those who use English as a Native Language, distinguishing between members and non-members of the Commonwealth, and those who use English an official second, or semi-official language. Other concepts, such as the different varieties or ELF communication between non-native speakers, were not explicitly referenced in any of the books.

\section{Discussion}

The analysis of textbooks leads us to question the relevance of the depictions of English with the real-life future needs of German students. In terms of the target interlocutor, research indicates that Germans are more likely to use English with other non-native speakers, be it at work, in social circles, or for travel purposes. The European Commission (2012) indicates, for example, that English is the primary foreign language in Germany, and that $64 \%$ of Germans will most often use their foreign language skills when they go on holiday. However, Inner Circle countries were not within the top ten travel destinations for Germans in 2013. Germans travel to Spain (12.6\%), Italy (7.6\%), and Turkey (7.6\%) in greater numbers than the UK and Ireland. It can be concluded, therefore, that the English language textbooks in this study do not posit other Europeans as target interlocutors, and thus may not truly be representative of German students needs.

In terms of linguistic models, the textbooks' overemphasis on RP accented English will do little to prepare students to understand the diversity of spoken English around the world-a fact that also holds true even for German students travelling to the UK. For example, RP accent is spoken by 3-6\% of the UK population (Galloway and Rose 2015), so it cannot even be considered as representative within its country of origin. A more representative textbook could have incorporated more World Englishes, as well as ELF interaction and pronunciation of various European non-native speakers, particularly focusing on the Englishes likely to be encountered by German students. Many of the books do include discussion of Englishes in the Outer Circle, so this can certainly be seen as a positive example of exposing students to the notion that Englishes differ across linguistic communities, and does a lot to raise awareness of the legitimacy of Outer Circle varieties. The increase of World Englishes exposure is seen as vital in today's ELT classroom - particularly in contexts where students are likely to engage with speakers from diverse linguistic backgrounds. While it is not advisable or feasible to expose students to all varieties, these textbooks are clearly illustrating an uneven depiction of models of English in modern day use. It is important to note however, that textbooks by their very nature represent contained an uncontroversial, idealized view of the world that is often culturally biased (Crawford 2002), and thus teachers will often supplement them with authentic materials, as was done in Galloway and Rose's (2014) study where students selected World Englishes varieties in an autonomous learning task. Thus, although our analysis of the textbook may not offer a full picture of classroom practices in Germany, we concur with researchers such as Suzuki (2011), who advocate for the diversity 
of English to be appreciated by teachers so that this knowledge can be transferred their students.

Thirdly, depiction of static cultures is incongruent with current thinking of language and culture, a result which corresponds to other findings investigating the role of culture in ELT (e.g. Baker, 2015). Traditional ELT approaches often have aimed to educate students of idealized versions of British, American, and other inner circle cultures. Textbooks have often positioned a goal of learning English to become part of this culture. This static view of culture is somewhat antiquated with current research into culture and language, which shows culture to be a fluid and negotiable concept. However, some of the tasks did highlight the multicultural aspects of inner circle countries, thus showcasing a degree of fluidity in their depictions of culture. However, ELF research has also shown that cultures are created in each instance of communication, and different communities of practice can be bound by their own culture norms and customs. We would suggest that textbooks that aim to teach English as a global language need to move away from presenting fixed inner circle cultures (although the positive presence of multiculturalism is noted), and instead highlight the dynamic cultures that English is used in today. Many students are no longer learning English to join an inner circle culture, thus textbooks may need to reflect this sociolinguistic reality in order to help innovate teaching practices.

Finally, the textbooks in question need to be commended for positive depictions of English as Global language. The textbooks make clear efforts to position English as a global language in its coverage of some outer circle contexts of English usages, and the inclusion of maps illustrating where English is used. We would argue that even more could be done in this vein to educate students on their likely future use of English. Not only by including a richer variety of accents and countries but also by addressing the negative connotations associated with the global spread of English, such as the notion of linguistic imperialism or the inequalities between inner and outer circle countries. Recent research findings have shown that learning about the spread of English and how English is used in the world today can help students move beyond the native-speaker norms perpetuated in teaching materials and by teachers themselves. For example, a study by Galloway (2013) looked at raising awareness of Global Englishes in traditional ELT classrooms. This study showed that awareness raising caused an increase in student self-confidence as non-native speakers of the language, and had changed their perceptions on how they would use English in the future.

\section{Conclusion: Implications for Innovation in English Language Teaching}

Although this article has focused on English language textbooks used in the German school system, the case is indicative of the types of materials used across Europe and further afield. With the growth of English as a European lingua franca, we expected to find more diverse depictions of English language use than would normally be found in commercial textbooks aimed at a general worldwide audience. The nature of the German books, having been created for the original purpose of educating students of English with the stated goal of using the language as a lingua franca, should have allowed for more tailored tasks aimed at German students' likely future use of English as a European lingua franca. However, we conclude that the depictions of English language, perceived future use, culture, and target interlocutors were not entirely representative of how German students would be likely to use English in their future - surveys into language use within the EU, and of German travel patterns have shown that these students are likely to use the English language within mainland Europe and with other Europeans in business, leisure, and educational settings. Thus a clear conclusion 
can be drawn that textbooks do not accurately meet students' needs in terms of their actual future use of the language.

It is important to reiterate that a textbook is often only one element of the curriculum, and teachers in Germany may very well be supplementing these state-approved textbooks with other sources of materials. In fact recent trends in teacher training have encouraged teachers to expose students to the sociolinguistic diversity of English use today- thus, this innovation may already be occurring outside of textbook-driven teaching. However, while many English language teachers might want to increase exposure to global uses, they are still constrained by a severe lack of materials to enact change in their classrooms. As Matsuda notes:

Few teachers, however, have a rich enough knowledge of and personal experience with all of the varieties and functions of Englishes that exist today, and, thus, they need to rely on teaching materials in order to introduce students to the linguistic and cultural diversity of English. (2012, 169)

Thus, the influence of textbooks on the way language is taught in the classroom and the way students view the language may continue to dampen innovation in this respect. While change might take time, small steps such as the inclusion of some representations of lingua franca usages of English, and outer and expanding circle contexts of English use in the textbooks examined in this study show that, even if underrepresented, some changes are beginning to come into effect.

\section{$\underline{\text { References }}$}

Baker, Will. 2012. From cultural awareness to intercultural awareness: culture in ELT. ELT Journal 66(1): 62-70. doi:10.1093/elt/ccr017.

Baker, Will. 2015. Research into Practice : Cultural and intercultural awareness. Language Teaching 48(1). 130-141. doi:10.1017/S0261444814000287.

Berns, Maggie, Marie-Therese Claes, Kees de Bot, Riet Evers, Uwe Hasebrink, Ineke Huibregetse, Claude Truchot, and Per van de Wijst. 2007. English in Europe. In M Berns, K de Bot, and Uwe Hasebrink (eds.), In the Presence of English: Media and European Youth, 15-43. New York: Springer.

Breiteneder, Angelika. 2009. English as a lingua franca in Europe: an empirical perspective. World Englishes 28(2). Blackwell Publishing Ltd. 256-269. doi:10.1111/j.1467971X.2009.01579.x.

Brenn-white, Prepared Megan \& Elias Faethe. 2013. English-Taught Master's Programs in Europe: A 2013 Update. New York: Institute of International Education.

Bruthiaux, Paul. 2003. Squaring the circles: issues in modeling English worldwide. International Journal of Applied Linguistics 13(2). Blackwell Publishing Ltd. 159-178. doi:10.1111/1473-4192.00042.

Crawford, Jane. 2002. The role of materials in the language classroom: Finding the balance. In JC Richards, \& WA Renandaya (eds.), Methodology in language teaching: an anthology of current practices, 80--95. New York: Cambridge University Press. 
D’Souza, Jean. 1999. Afterword. World Englishes 18(2): 271-274. doi:10.1111/1467971X.00139.

European Commission. 2012. 'Europeans and their languages'. Special Eurobarometer 386: 1-145. Retrieved from http://ec.europa.eu/public_opinion/archives/ebs/ebs_386_en.pdf

Friedrich, Patricia. 2012. ELF, intercultural communication and the strategic aspect of communicative competence. In A Matsuda (ed.), Principles and practices for teaching English as an international language, 44-54. Bristol: Multilingual Matters.

Galloway, Nicola. 2013. Global Englishes and English Language Teaching (ELT) - Bridging the gap between theory and practice in a Japanese context. System 41(3). 786-803. doi:10.1016/j.system.2013.07.019.

Galloway, Nicola \& Heath Rose. 2014. Using listening journals to raise awareness of Global Englishes in ELT. ELT Journal 68(4). doi: 10.1093/elt/ccu021

Galloway, Nicola \& Heath Rose. 2015. Introducing Global Englishes. Abingdon: Routledge.

Hilgendorf, Suzanne K. 2007. English in Germany: Contact, spread and attitudes. World Englishes 26(2): 131-148. doi:10.1111/j.1467-971X.2007.00498.x.

Hoffmann, Charlotte. 2000. The Spread of English and the Growth of Multilingualism with English in Europe. In J Cenoz \& U Jessner (eds.), English in Europe. The Acquisition of a Third Language, 1--21. Clevedon: Multilingual Matters.

Jenkins, Jennifer. 2006. Points of view and blind spots: ELF and SLA. International Journal of Applied Linguistics 16(2). 137-162. doi: 10.1111/j.1473-4192.2006.00111.

Kachru, Braj B. 1985. Standards, codification and sociolinguistic realism: the English language in the outer circle. In R Quirk and $\mathrm{H}$ Widdowson (eds.), English in the World: Teaching and Learning the Language and Literatures, 11-30. Cambridge: Cambridge University Press.

Leung, Constant and Brian.V. Street. 2012. Linking EIL and Literacy: Theory and Practice. In Lubna Alsagoff, Sandra Lee McKay, Guangwei Hu \& Willy A. Renandya (eds.), Principles and Practices for Teaching English as an International Language, 85-103. New York: Routledge.

Matsuda, Aya. 2002. "International understanding" through teaching world Englishes. World Englishes 21(3). Blackwell Publishers Ltd. 436-440. doi:10.1111/1467-971X.00262.

Matsuda, Aya. 2012. Teaching Materials in EIL. In Lubna Alsagoff, Sandra Lee Mckay, Guangwei Hu \& Willy A. Renandya (eds.), Principles and Practices for Teaching English as an International Language. New York: Routledge.

Matsuda, Aya \& Patricia Friedrich. 2012. Selecting an instructional variety for an EIL curriculum. In Aya Matsuda (ed.), Principles and practices of teaching English as an international language, 17-27. Bristol: Multilingual Matters. 
Mauranen, Anna. 2012. Exploring ELF: Academic English shaped by non-native speakers. Cambridge: Cambridge University Press.

Ministerium für Schule und Weiterbildung des Landes Nordrhein-Westfalen. 2007.

Kernlehrplan für den verkürzten Bildungsgang des Gymnasiums - Sekundarstufe I (G8) in Nordrhein-Westfalen. English. Retrieved from

http://www.standardsicherung.schulministerium.nrw.de/lehrplaene/upload/lehrplaene_d ownload/gymnasium_g8/gym8_englisch.pdf

McKay, Sandra Lee. 2012. Teaching materials for English as an international language. In Aya Matsuda (ed.), Principles and practices of teaching English as an international language, 70-83. Bristol: Multilingual Matters.

Montgomery, Scott L. 2013. Does Science Need a Global Language?: English and the Future of Research. Chicago: University of Chicago Press.

Mufwene, Salikoko S. 2001. The ecology of language evolution. Cambridge: Cambridge University Press.

Seidlhofer, Barbara, Angelika Breiteneder \& Marie-luise Pitzl. 2006. English as a lingua franca in Europe: challenges for applied linguistics. Annual Review of Applied Linguistics 26: 3-34. doi:10.1017/S026719050600002X

Suzuki, Ayako. 2011. Introducing diversity of English into ELT: student teachers' responses. ELT Journal 65 (2): 145-153. doi:10.1093/elt/ccq024.

\section{TABLES 1-3}

Table 1: EFL vs ELF (Jenkins 2006)

\begin{tabular}{ll}
\hline EFL & ELF \\
\hline Part of modern foreign languages & Part of World Englishes \\
Deficit perspective & Difference perspective \\
$\begin{array}{l}\text { Transfer/interference and fossilization } \\
\text { metaphors }\end{array}$ & Contact/evolution metaphor \\
$\begin{array}{l}\text { Conformative, monolingual bias } \\
\text { Code-switching/code mixing viewed as } \\
\text { interference error }\end{array}$ & \begin{tabular}{l} 
Transformative, bilingual \\
Code-switching/code mixing viewed as \\
\hline
\end{tabular}
\end{tabular}


Table 2: Differences between GELT and Traditional ELT (Galloway and Rose 2015, p. 208)

\section{Traditional ELT $\quad$ GELT}

\begin{tabular}{|c|c|c|}
\hline $\begin{array}{l}\text { Target } \\
\text { interlocutor }\end{array}$ & Native English speakers & $\begin{array}{l}\text { Native English speakers \& non- } \\
\text { native English speakers }\end{array}$ \\
\hline Owners & Native English speakers & $\begin{array}{l}\text { Native English speakers \& non- } \\
\text { native English speakers }\end{array}$ \\
\hline Target culture & Fixed native English culture & Fluid cultures \\
\hline Teachers & $\begin{array}{l}\text { Non-native English speaking } \\
\text { teachers (same first language) and } \\
\text { native English speaking teachers }\end{array}$ & $\begin{array}{l}\text { Non-native English speaking } \\
\text { teachers (same and different first } \\
\text { language), native English speaking } \\
\text { teachers }\end{array}$ \\
\hline Norms & $\begin{array}{l}\text { Native English and concept of } \\
\text { Standard English }\end{array}$ & $\begin{array}{l}\text { Diversity, flexibility \& multiple } \\
\text { forms of competence }\end{array}$ \\
\hline Role-model & Native English speakers & Successful ELF users \\
\hline Materials & $\begin{array}{l}\text { Native English and native } \\
\text { English speakers }\end{array}$ & $\begin{array}{l}\text { Native English, non-native English, } \\
\text { ELF and ELF communities \& } \\
\text { contexts }\end{array}$ \\
\hline $\begin{array}{l}\text { First language } \\
\text { and own culture }\end{array}$ & $\begin{array}{l}\text { Seen as a hindrance and source of } \\
\text { interference }\end{array}$ & Seen as a resource \\
\hline
\end{tabular}

Table 3: Framework for textbook analysis used in the study

\begin{tabular}{lll}
\hline & EFL-oriented ideology & $\begin{array}{l}\text { Global Englishes- } \\
\text { oriented ideology }\end{array}$ \\
$\begin{array}{lll}\text { Who are positioned as } \\
\text { the owners of English? }\end{array}$ & $\begin{array}{l}\text { Native speakers, with an } \\
\text { emphasis on inner circle } \\
\text { use }\end{array}$ & $\begin{array}{l}\text { Native and non-native } \\
\text { speakers, with emphasis } \\
\text { on global use }\end{array}$ \\
$\begin{array}{l}\text { Who are the target } \\
\text { interlocutors in the } \\
\text { materials? }\end{array}$ & NESs & NESs and NNESs \\
\hline $\begin{array}{l}\text { What models and norms } \\
\text { of English are presented } \\
\text { in the book and audio } \\
\text { materials? }\end{array}$ & $\begin{array}{l}\text { Inner circle NEs; English } \\
\text { as standard and static }\end{array}$ & $\begin{array}{l}\text { World Englishes; English } \\
\text { as diverse and flexible }\end{array}$ \\
$\begin{array}{l}\text { How is culture depicted } \\
\text { in the materials? }\end{array}$ & $\begin{array}{l}\text { As fixed inner circle } \\
\text { cultures }\end{array}$ & As fluid, global cultures \\
\hline
\end{tabular}

